\title{
The Chinese path of integration and development among all ethnic groups from a comparative perspective between China and the west
}

\author{
Shaoqing Zhou ${ }^{1}$
}

Received: 5 November 2021 / Accepted: 5 November 2021 / Published online: 09 December 2021

(c) The Author(s) 2021

\begin{abstract}
By comparing five aspects between China and the West-ideas, model of political participation, path of economic and social development, pattern of protection of language and culture rights, and construction of national cohesion and social (Minzu) solidarity, this paper reveals that the Chinese path of integration and development among all ethnic groups has the following characteristics: the ideas of equality, solidarity, mutual assistance and harmony among all ethnic groups; the integrative participation model of all ethnic groups under the unified leadership of the Communist Party of China; the integration on the economic and social development (common prosperity and development); equal protection of the language and culture rights of all ethnic groups; strong sense of national cohesion and social solidarity of fifty-six ethnic groups, based on the equal emphasis on the individual and collective rights as well as the close integration between political value and traditional cultural value. In general, China's ethnic policies embody both specific rights and the level of community with a common future. Under the leadership of the Communist Party of China, relations between ethnic groups are harmonious and positive, and development of all ethnic groups tends to achieve a real equality. In Western countries, ethnic (or racial) relations remain relatively stable with fluctuations from time to time, and the development gap between ethnic groups has a trend of further expansion. Different ideas, systems and cultural concepts lead to different ethnic relationships and current situations of development between China and the West.
\end{abstract}

Keywords China $\cdot$ Western countries $\cdot$ Ethnic minorities $\cdot$ Rights $\cdot$ Development

Shaoqing Zhou

zhousq@ cass.org.cn

1 Senior Researcher of the Study Division of World Peoples, the Institute of Ethnology and Anthropology, the Chinese Academy of Social Sciences, Building 6, No.27 Zhongguancun Nan Dajie, Haidian District, Beijing 100081, China 


$\begin{array}{ll}\text { Abbreviations } \\ \text { IHRLCPT } & \begin{array}{l}\text { International Human Rights Law Curriculum Project Team } \\ \text { PRC }\end{array} \\ \text { the People's Republic of China } \\ \text { SCIO } & \text { the State Council Information Office of China } \\ \text { UK } & \text { the United Kingdom of Great Britain and Northern Ireland } \\ \text { UN } & \text { the United Nations }\end{array}$

\section{Introduction}

Seventy years ago, in the middle of the twentieth century, world history entered a new stage. After the end of World War II, Western countries suffering from the disasters of war entered a period of recovery and reconstruction. In 1949, the People's Republic of China (the PRC or China) was established, and under the leadership of the Communist Party of China, it began to enter the construction period on a large scale. In terms of time nodes, most Western countries at that time had experienced the construction and development of the nation-state for hundreds of years, but domestic ethnic issues in many countries were still outstanding, ${ }^{1}$ withsome countries even having experienced or engaged in ethnic cleansing and genocide. China had also just gone through wars, and its period of the construction of a modern nation-state was only decades. Therefore, it could be said that both China and the West faced arduous tasks in dealing with or responding to ethnic issues.

We see different results seventy years later: some Western countries have faced serious problems of immigration integration and ethnic (regional) separatism since entering the twenty-first century under the historical condition of having basically solved "ethnic issues." At the same time, under the new historical condition, the problem faced by natives who survived the early colonial period appeared in the international community, challenging people's existing preconceptions. In contrast, under the leadership of the Communist Party of China, the PRC, where many things were still waiting to be done, has continuously and creatively applied Marxism, and through a series of effective innovations in ideas, systems, and mechanisms, the PRC has made historic achievements in solving ethnic issues. Comparing the gains and losses of some Western countries and the PRC in solving ethnic issues can not only better summarize the valuable experiences of the PRC in the seventy years since its founding, highlighting the achievements of the Chinese example, but can also contribute the PRC's unique wisdom in solving ethnic issues to the international community. The Chinese road to solving ethnic issues over its seventy years is the path of integration and development among all Chinese ethnic groups. The scientific connotations can be summarized as follows: the development

\footnotetext{
1 The larger part of this paper is a comparison and dialogue between China and the West, and the background and types of ethnic groups involved will be diverse. In terms of conceptual processing, based on Chinese discourse, the author will in principle refer to ethnic groups in sub-nations as ethnicities and ethnic minorities. At the same time, some ethnic groups at the sub-national level will be referred to as "minority groups" in combination with relevant contexts. These contexts include some idiomatic usages in international academia and documents, the most typical of which are immigrant ethnic minorities.
} 
process of the integration of all aspects of different ethnic groups, such as political participation, economic and social development, and guarantee of language and cultural rights, is provided by the Chinese government under the unified leadership of the Communist Party of China; while guaranteeing the rights of ethnic minorities, the Chinese government integrates the development of all ethnic groups with the national development, to shape a community of a shared future for the Chinese nation. This approach is obviously different from the practice of Western countries governed under the multi-party system, which simply adopts the "rights protection" differentiation method to solve ethnic minority's development issues.

\section{A comparison of ideas about ethnicity}

\section{Several major ideas about ethnicity}

Ideas about ethnicity reveal the values related to ethnic issues and have an important position in the formulation of ethnic policies, legislation, or systems. Different ideas produce different policies, legislation, or systems, which in turn produce different political and social effects. In some cases, though the texts of policies, legislation, and systems are the same, the practical effects might be very different due to the different ideas running through them (Shaoqing 2015a, 2015b).

Since colonialism started the world system and caused further interactions between nationalities or ethnicities, at least five ideas of different nature have emerged in the involvement or in the handling of ethnic issues. They are racism, assimilationism, liberalism, multiculturalism, and Marxism. These five ideas have a strong influence on ethnic relations, political ecology, economic and social development, and cultural ecology in relevant countries and regions and in different historical times and spaces.

The idea of racism, or more accurately, the concept of racism, is a set of worldviews and values that suggest that some races are superior to others. As a mature idea or concept, the emergence of racism has a profound colonialist historical background and a racial cultural background of "Eurocentrism" as well, and is the product of the externalization of modern European history.

Racism depends on non-selectable biological characteristics such as bloodline and skin color. It is strong exclusive. People whose races are regarded as inferior are either discriminated against, excluded, oppressed, or subject to expulsion, and "ethnic cleansing," sometimes resulting in slaughter. Common manifestations of the idea or concept of racism include racial prejudice, racial discrimination, racial exclusion, apartheid, racial conflict, ethnic cleansing, genocide, etc. ${ }^{2}$ Racism has had disastrous consequences in history. In reality, racism is also an important cause of tension in racial or ethnic relations in many countries.

\footnotetext{
${ }^{2}$ Similarly, there are also "conflicts of civilizations," absolute "cultural evolutionism,"“new racism" or "cultural racism" ideas or concepts. Advocators of such ideas or concepts often put on the guise of "objective research" to divide the cultural types studied into "backward" and "advanced," and even directly determine "superior or inferior," thereby intentionally or unintentionally placing specific groups at a disadvantaged position. Since the beginning of the twenty-first century, with the invasion of major powers, the maneuvers of geopolitics, and the rise of various ethnic nationalism models worldwide, new racism has shown a tendency to returning directly to traditional racism.
} 
The idea of assimilationism means that a nation forces its disadvantaged minority groups to accept the traditions, culture, language, religion, and values of the principal or major ethnic group. Assimilationism can be divided into various forms such as directly compulsory assimilationism, integrationism, and civicism. The idea of assimilationism emerged during the period of Western colonialism and after the formation of the Westphalian system of state sovereignty, and gradually reached its climax in the era of nation-states. Compared with the idea of racism, assimilationism has certain historical significance to progress. It breaks through the "closeness of racism's demarcation based on biological characteristics such as bloodline and skin color and the resulting strong exclusion, to a certain extent, make nation-states an open system that can accept 'others' and allow them to objectively have the function of promoting the unity and territorial integrity of nation-states" (Shaoqing 2015a, 2015b). Of course, with the progress of the times and the popularization of concepts and systems related to human rights, the idea of assimilationism is not only more and more outdated but also counterproductive in terms of actual results.

The idea of liberalism refers to the protection of the cultural, linguistic, and religious rights of individual members of minority groups when the nation promotes the political integration of inter-ethnic relations. The idea of liberalism is a concrete manifestation of the concepts and values of modern liberalism and individualism in solving ethnic issues. According to such concepts and values, all individuals, including members of minority groups, are equal in law and enjoy equal political participation, and economic, social, and cultural rights. No one should be discriminated against due to his or her origin or background including ethnicity (or race), culture, or religion. The idea of liberalism emphasizes the "equal" protection of the rights of all people, including members of ethnic minorities, with indiscriminate individual rights and freedoms. For the first time in history, at the level of formal or procedural justice, comprehensive equality between minority and majority groups has been achieved.

The idea of multiculturalism refers to considering the group culture and characteristics of minority groups in the political process of a nation, tolerating the differences of minority groups in the building of civic state, and giving them the concept and idea of multicultural citizenship. Multiculturalism emerged in the United States in the early twentieth century. Its original intention was "anti-AngloSaxonization" and "anti-assimilation," emphasizing equality among ethnic groups. Starting from the 1970s, multiculturalism was introduced as a formal official policy in Canada. The idea of multiculturalism is a rectification of liberalism that excessively ignores the culture and environment of individual growth and the significance of groups to individuals. Such an idea advocates that we should not only "guarantee the equal rights of every citizen, but also grant minority groups different citizenship to recognize and accept the special identities and needs of minority groups and "give them different rights based on their different cultural identities" (Shiyin 2009). 
The internal pedigree of the idea of multiculturalism is very complex. Specifically, liberal multiculturalism, with the most influence, attempts to reconcile the individual rights of liberalism and the group rights of multiculturalism, advocating granting minority groups a certain degree of group rights under the condition of insisting on individual rights. It should be emphasized that although the idea of multiculturalism was proposed by Western countries to ease racial or ethnic conflicts, in practice it mainly targets immigrant minority groups. In terms of effect, it plays a positive role in the social integration of immigrants.

Marxist ethnic ideas suggest that all nationalities are equal. This is the sum of Marxist concepts and values for dealing with ethnic issues, and was gradually formed by proletarian parties and socialist countries in their long-term phases of revolution and construction, and embodied and contained in the writings of classic Marxist theorists and politicians and the policies and practices of relevant countries. The Marxist value of ethnic equality not only bears a class and historical nature, but also bears a nature of development and continuity. At the same time, it holds the idea of integrity and comprehensiveness, which is a valuable spiritual wealth shared by human society. Specifically, Marxism has the following characteristics: a view of class interests that transcends nationalism; a view of justice that focuses on liberating all humanity; a view of human rights that eliminates class oppression and class exploitation; a view of culture that recognizes cultural diversity (Shaoqing 2015a, 2015b).

Marxism offered, for the first time in human history, the idea of ethnic equality which is truly concerned about the survival and fate of disadvantaged ethnic groups; it places different ethnic groups in a completely equal "brotherhood relationship" (Marx and Engels 1847), or a "comradeship"(Lenin 1914). The ultimate mission of Marxism's ethnic ideas is to eliminate classes, eliminate oppression, and liberate all ethnicities, including ethnic minorities, and even all mankind. Before this goal is achieved, Marxism's ethnic ideas attach great importance to the equal status of various ethnic groups, and ensure equal relations among them with solid political equality and policy guarantees. The pursuit of true equality for various ethnic groups is, in reality, the essence of Marxist ethnic ideas and the fundamental difference between Marxism and the above-mentioned ideas of racism, assimilationism, liberalism, and multiculturalism.

\section{Differences in China's and major Western countries' ideas about ethnicity}

Around the middle of the twentieth century, both Western countries and China entered a period of large-scale construction or reconstruction. World War II had devastated many Western countries and made them aware that the protection of minority groups was largely crucial to the security of entire countries and the 
fate of all people. ${ }^{3}$ In view of this, after World War II, under the dominance of Western countries such as the United States, Britain, and France, the international community began to systematically reflect on the "minority issues" that were widespread in the world at that time. The Constitution of the United Nations Educational, Scientific and Cultural Organization, adopted in November 1945, states: "That the great and terrible war which has now ended was a war made possible by the denial of the democratic principles of the dignity, equality and mutual respect of men, and by the propagation, in their place, through ignorance and prejudice, of the doctrine of the inequality of men and races." The three important legal documents called the "International Bill of Human Rights" unanimously declare that "the recognition of the inherent dignity and of the equal and inalienable rights of all members of the human family is the foundation of freedom, justice and peace in the world." (IHRLCPT 2002) The UN General Assembly Resolution titled "Fate of Minorities" states that "the United Nations cannot remain indifferent to the fate of minorities." (United Nations 1948) During this period, the UN's idea on the protection of minority rights basically adopted a "liberal" paradigm, that is, equally protecting the individual rights of members of minorities (including minority ethnic groups). According to the Universal Declaration of Human Rights, "All human beings are born free and equal in dignity and rights," and that "everyone is entitled to all the rights and freedoms set forth in this Declaration, without distinction of any kind, such as race, color, sex, language, religion, political or other opinion, national or social origin, property, birth or other status"; the International Covenant on Civil and Political Rights and the International Covenant on Economic, Social and Cultural Rights have taken similar paths (IHRLCPT 2002).

It was worth noting that while Western countries, represented by the United States, were leading the international community to formulate international human rights law based on the idea of liberalism, there was another picture within Western countries. Taking the United States as an example, after the end of World War II, the United States vigorously "promoted" on the international stage the value of liberalism that suggested that all ethnicities were equal, while publicly promoting racism within its own country. In fact, until the 1950s, segregation and racial discrimination in the United States were widespread, and laws that publicly segregated and discriminated against African-Americans abounded. In some states, such as South Carolina, Alabama, Georgia, and others in the American South, there was no penalty for killing Black people (Franklin et al. 1988). In 1954, the US Supreme Court declared that segregation was illegal, and the massive social unrest culminating in the Civil Rights Movement began to change the United States' treatment of so-called "colored people." Since the 1960s, liberal multiculturalism-led by liberalism and supplemented by multiculturalism — has gradually become a mainstream value for dealing with minority issues. In terms of the protection of native minorities, the United

\footnotetext{
3 The Nazi nationalism that killed nearly six million Jews not only brought Germany and Germans to the brink of collapse, but also affected the entirety of Europe and even the world. Here, the fate of minority groups is mutually crucial to the fate of the majority of people or an entire country.
} 
States also experienced two historical stages from full assimilation to support of native autonomy after World War II.

In France, after the end of World War II, due to the need for post-war reconstruction and economic development, a large number of immigrants with greatly different native cultures were introduced from overseas. These immigrant groups, together with the native French ethnic groups such as the Corsicans, Bretons, and Basques, constituted French "minorities" of academic significance. Because of its long-term adherence to the "inseparable French nation" and the non-recognition of the existence of "minorities," France adopted the idea of civil liberalism in dealing with ethnic issues, that is, it did not recognize any "nation" or "ethnic group" other than that of the "French nation."

Canada is a typical multi-ethnic country. Over the nearly one hundred years before World War II, Canadian authorities adopted racist and assimilationist strategies for their native minorities, French minorities, and new immigrant groups. With the promulgation of the Canadian Citizenship Act after World War II, Canada gradually adopted the liberalism model in which "all citizens are equal."4 Since 1971, after meeting with failure and resistance in solving ethnic issues through liberalism and the "dual culturalism" model, Canada has implemented multicultural ideas and policies among the three major minority groups throughout the entire confederation.

Since the beginning of the twenty-first century, with the escalation of the problems of immigration, especially related to refugees, the existing ethnic ideas of some European and North American countries have been shaken. In the United States, traditional ideas of liberalism and multiculturalism are challenged by Christian nationalism and even white supremacy. In Western Europe, many countries, including France, have successively declared "the failure of multiculturalism."

In general, since World War II, the overall idea maintained by European and American countries in dealing with their minority issues has been "liberal-"or "civic-" "multiculturalism." However, due to path-dependence (or historical inertia) and external stimuli, the ethnic ideas held by Western countries present a situation in which multiple ideas such as liberalism, racism, assimilationism, and multiculturalism alternate or overlap — there are repeats or even backward tendencies. This is in stark contrast to China.

The Communist Party of China has always adhered to the Marxist idea of equality among all ethnicities. Before coming to power, the Communist Party of China gradually formed an understanding of the national conditions of China's "unified multi-ethnic nation" and recognized the reality of China's multi-ethnic coexistence. In interaction and communication with the ethnic groups, it established the idea of equality summarized by the statement that "we must help the ethnic minorities liberate themselves in politics, economy, and culture," and by the belief that "recognizing that all minorities in China have the equal right of self-government"(Declaration

\footnotetext{
${ }^{4}$ Prior to this, even the British ethnic groups recognized themselves as "British subjects" and lacked the recognition of Canadian subjects.

5 Of course, Spain was an exception during this period. Under the dictatorship of Franco, the Spanish government (1939-1975) pursued compulsory assimilation as a long term goal.
} 
1947) was the correct way to solve the ethnic issues in China. On the eve of the founding of the PRC in September 1949, the Common Program of the Chinese People's Political Consultative Conference, formulated with a temporary constitutional status, provided for the basic ideas that continue - to this day - to guide ethnic relations, namely "equality, unity, and mutual assistance." ${ }^{\text {TT }}$ These three major ideas were enshrined by the 1982 Constitution of the People's Republic of China. With the deepening of reform and opening up, the 2005 Central Conference on Ethnic Affairs further put forward the notion of "harmony" on the basis of the ideas of "equality, unity, and mutual assistance." When the constitution was revised in 2018, the four ideas of "equality, unity, mutual assistance, and harmony" were formally enshrined by the constitution, becoming constitutional ideas and principles that guide China's settlement of ethnic issues.

In particular, compared with Western countries, China's ideas for solving ethnic issues have two distinct characteristics. One is to maintain stability over a long time; the other is to adopt a series of effective policies and legislations to promote de facto equality among all ethnicities while emphasizing their equal status. In fact, it is this long-term, stable, and effectively practicable idea that makes China unique in solving ethnic issues - China has formed the path of ethnic integration and development with Chinese characteristics, and made major achievements that other multi-ethnic countries in the world have found impossible to achieve.

\section{Comparison of ethnicities' political participation system and practice}

\section{Main types of political participation system of Western ethnic groups}

Political participation is an important variable that affects ethnic relations and issues. According to the traditional liberal view, the construction and political participation of a multi-ethnic country is almost an unsolvable difficulty. John Stuart Mill believed that national consistency (homogenization) is the basic premise for the construction of a "free and democratic" country. "The coexistence of ethnicities or ethnic groups in a country is not conducive to the establishment of representative democracy. In a nation composed of ethnicities, a free system is simply impossible. Among a people (ethnicity) that lacks common feelings and especially uses different languages, the existence of unified public opinions necessary for the implementation of a representative government is impossible."(Mill 1982) Since the 1970s and 1980s, Western countries that are multi-ethnic have made great progress in the construction of the participatory political system. Many countries have begun to explore institutional channels for the acceptance of minority groups' political participation on the basis of adherence to "homogeneous" universal suffrage and parliamentary democracy. Accordingly, there are two representative system types:

\footnotetext{
6 These three major ideas later developed into the principle of national equality, the principle of national unity, and the principle of common prosperity for all ethnicities, which became the three basic principles for dealing with China's ethnic relations.
} 
one is Arend Lijphart's "consociationalism," ${ }^{7}$ and the other is Donald L. Horowitz's "centripetalism."

Consociationalism and the centripetalism are important theoretical findings and practical summaries of Western countries' experiences exploring multi-ethnic political participation. What both models have in common is that they recognize that the traditional liberal homogenization path is not conducive to the political participation of minority groups, that the solution to the problem lies in redesigning the institutional framework of power-sharing, and that institutional innovation in the political process may improve the political participation of minority groups, thereby enhancing the political identity of a multi-ethnic country and reducing conflicts among ethnic groups. The difference is that consociationalism tends to use a largescale coalition government, group autonomy, ${ }^{9}$ proportional representation, minority veto power, and other institutional innovations to promote political participation by minority groups when boundaries of ethnic groups are solidified; centripetalism

\footnotetext{
${ }^{7}$ Lijphart was interested in the political participation and political stability of multi-ethnic countries when studying the political systems of countries such as Belgium. In 1969, he published a paper titled "Consociational Democracy,"in which he proposed and preliminarily discussed the concept of "country of consociational democracy." Lijphart proposed that, according to the theory of crosscutting cleavages, countries with diverse sub cultural and cultural competitions such as the Netherlands, Switzerland, and Austria should be unstable, but this is not the fact. Lijphart referred to these "fragmented but stable" exceptional countries as "countries of consociational democracy," and believed that the in-depth analysis or understanding of this phenomenon would find the third external variable, that was "behavior of political elites" apart from "political culture" and "social structure." On this basis, Lijphart published Democracy in Plural Societies (Democracy in Plural Societies: A Comparative Exploration, Yale University Press, 1977), which comprehensively expounded his viewpoints and positions on consociational democracy. In 1999, Lijphart, in his monograph Patterns of Democracy: Government Forms and Performance in Thirty-Six Countries (Patterns of Democracy: Government Forms and Performance in ThirtySix Countries, Yale University Press, 1999), upgraded consociational democracy to a far-reaching "consensus democracy." During decades of controversy, Lijphart gradually revised and perfected his theory. See Arend Lijphart, "Consociational Democracy," World Politics, Vol.21, No.2, 1969.

${ }^{8}$ In his Ethnic Groups in Conflict (Ethnic Groups in Conflict, Berkeley: University of California Press, 1985 ) and other series of works, Donald L. Horowitz elaborated an idea different from Lijphart's idea on "consociationalism." His "centripetalism" emphasizes cooperation, mutual adaptability and integration among ethnic groups, and avoids the political participation by ethnic groups along the ethnic boundaries to the greatest extent possible. In this regard, Horowitz advocated design and transformation conducive to incentives or encouragement of the union of ethnic groups for election systems and party politics. Horowitz criticized Lijphart's line of solidifying "ethnic politics," arguing that consociational democracy was not suitable for those societies with "extremely divided ethnic groups." See Donald L. Horowitz, "Constitutional Design: Proposals versus Processes," in Andrew Reynolds (ed.), The Architecture of Democracy: Constitutional Design, Conflict Management and Democracy, Oxford University Press, 2002, p.23.

${ }^{9}$ As a system for solving political participation in a multi-ethnic country, proportional representation appeared much earlier than when "consociationalism" was proposed. Early in 1899, Belgium, which was deeply troubled by ethnic and religious issues, decided to employ proportional representation to elect members of Parliament, and had thus become the first country in the world to adopt proportional representation to elect representatives of the House of Commons, the legislative organ. In 1906, Finland also began to employ proportional representation in response to the appeal for political participation by Swedish ethnic minorities in the country. By the 1920s, most European countries had adopted proportional representation to differing extents to solve the problem of political participation by multiple ethnic groups in the country. See Yan Qing, Niu Pengli: "Analysis of Political Participation by Ethnic Minorities under the Framework of Proportional Representation," Ethno-National Studies, 《民族硎究》 No.2, 2017.
} 
tries to break down ethnic barriers in political participation and power sharing with the designs of cross-ethnic or trans-ethnic systems such as alternative voting systems, establishment of centrist alliances, regional presidential electoral systems, and administrative federalism when promoting multi-ethnic groups' political participation. "From the perspective of theoretical logic, consociationalism mainly" achieves different ethnic groups' political participation "by ensuring the effective representation and participation by various ethnic groups in the political process and decision-making process." Centripetalism places emphasis on inter-ethnic integration, considering that political participation "could not simply be based on existing ethnic differences and make inter-ethnic differences highly politicized, but tries to induce inter-ethnic cooperation and adjustment before the election or during the process of collecting votes to reduce the degree of politicization in inter-ethnic differences through incentives"(Hongyuan 2012).

Consociationalism and centripetalism, as well as traditional liberal homogenization, constitute three important system types of political participation by ethnic groups in Western countries. ${ }^{10}$

\section{A comparative analysis of China's and major Western countries' systems and practices for solving ethnic issues}

China's system and practice for minority groups' political participation were initiated long before the founding of the PRC. ${ }^{11}$ In order to ensure orderly and effective political participation by minority groups, the Chinese government began ethnic identification work shortly after the founding of New China. ${ }^{12}$ At the system level, the Communist Party of China led the formulation of a series of laws and regulations such as the constitution and the Regional Ethnic Autonomy Law, with the political participation rights of ethnic minorities thereby guaranteed by both the constitution and the Basic Law. At the same time, the Regional Ethnic Autonomy Law, amended in 2001, also defined the system of regional ethnic autonomy as "a basic political system of the country."

\footnotetext{
${ }^{10}$ It should be pointed out that the division of these three categories of systems is largely for the convenience of analysis. In reality, which countries fall under which categories is very complicated. Generally speaking, Belgium, the Netherlands, Switzerland, and Austria can be classified as countries employing consociationalism; Britain, Spain, and Canada can be classified as those employing centripetalism; France, Germany, and the United States can be classified as those employing liberal homogenization.

${ }^{11}$ Early in 1931, the Provisional Central Government of the Chinese Soviet Republic stipulated "citizenship of ethnic minorities" in its Constitutional Outline and confirmed the protection of their "cultural and language rights"; in 1947, under the leadership and help of the Communist Party of China, the Inner Mongolia Autonomous Region, the first provincial-level ethnic autonomous region in China, was established in the Mongolian settlement area that had been liberated. This is an important practice of the Communist Party of China to guarantee the political participation rights of ethnic minorities. See the United Front Work Department of CPC Central Committee: Literature Collection on Ethnic Issues, 《 民族问题文献汇编》P Party School of the Central Committee of C.P.C. Press, (中共中央党校出版社) 1991 Edition, p.166.

${ }^{12}$ Of course, the purpose of ethnic identification is not only to promote effective political participation by ethnic minorities, but also to better help ethnic minorities achieve economic and social development and the protection of cultural and language rights.
} 
At the practical level, the political participation by Chinese ethnic minorities is carried out at three levels. Firstly, at the national level, ethnic minorities directly participate in the country's political affairs according to a certain proportion of representatives ${ }^{13}$ through two major platforms, namely the National People's Congress and the Political Consultative Conference. ${ }^{14}$ Secondly, at the level of local ethnic autonomy, in accordance with the provisions of relevant laws and policies, ethnic minorities directly participate in the governance of local affairs. ${ }^{15}$ Thirdly, in nonethnic autonomous areas, ${ }^{16}$ ethnic minorities participate in local affairs in such areas through certain policy designs.

The political participation by Chinese ethnic minorities is carried out in an extensive, multi-level, multi-channel, and more importantly, blended manner. ${ }^{17}$ In Belgium, Switzerland, and other countries that have adopted consociationalism, although these multi-ethnic Western countries have also achieved relatively sufficient ethnic political participation, such sufficient participation is often accompanied by the adverse consequence of the loss of national unity. In Belgium, the political participation by ethnic groups strictly adheres to proportional representation. In actual operation, the whole of Belgium is increasingly divided into two camps, namely the Flemish speaking Dutch and the Walloon speaking French. The country is almost divided into two parts along the boundaries of language families,

\footnotetext{
13 The Political Consultative Conference system is a major institutional innovation for the Communist Party of China to resolve the issues of political participation by ethnic minorities. Through political consultation, democratic supervision, and political participation in the Political Consultative Conference, minority groups play an important role in promoting the development of ethnic areas in national and local affairs and protecting the rights of ethnic minorities.

${ }^{14}$ At the level of the National People's Congress, the number of delegates from minority groups has always been much higher than the proportion of their population. From the 7th to the 12th National People's Congress, the proportions of delegates from minority groups exceeded $13.69 \%$, with the highest being $15 \%$, significantly higher than the proportions of the minority population in the national population during the same period. At the same time, the Electoral Law clearly stipulates that "nationalities with exceptionally small populations shall each have at least one deputy." In every session of the National People's Congress, there are representatives from fifty-five ethnic minorities. See Kan Ke: "Why Should the proportions of delegates from ethnic minorities be greater than their population proportions?" The People's Congress of China, 《中国人大》 No.22, 2017.
}

${ }^{15}$ In the standing committees of the people's congresses of 155 ethnic autonomous areas, directors or deputy director positions are assumed by citizens of ethnic autonomous areas; the positions of chairmen, governors, county heads or banner heads of governments of ethnic autonomous areas shall be assumed by citizens of ethnic autonomous areas. As of 2018 , the total number of ethnic minority cadres in China exceeded three million, which was more than three times the number in 1978. Of the fifty-fiveethnic minorities, fifty-three have established ethnic autonomous areas or ethnic townships. Such systematic, large-scale, and politically-minded minority autonomy practice is rare in today's world. See Zhou Shaoqing:"Chinese Human Rights Cause in Ethnic Minorities Having Made Historical Progress," China Ethnic News，《中国民族报》December 19, 2018.

${ }^{16}$ Ethnic minorities living in non-ethnic autonomous areas and "ethnic minorities living in ethnic autonomous areas where regional autonomy is not implemented" are also commonly referred to as "scattered ethnic minorities." See Luo Huiquan: "Problems, Causes and Countermeasures for the Training of Minority Cadres in Scattered and Mixed Areas," Journal of Hubei Institute of Socialism, 《湖北省社会 主义学院学报》N No.1, 2007.

${ }^{17}$ In China, no form of political participation by minority groups is separate. On the contrary, it is closely integrated with majority groups and national politics. China has neither political parties nor parliaments for ethnic minorities nor has it any form of political organizations demarcated by ethnicities. 
with such division resulting in the resignation of the prime minister, the replacement of the cabinet, and even the repeated emergence of anarchy. The biggest risk for Belgium in the twenty-first century is undoubtedly the division of the country. In contrast, Switzerland, which is also a multi-ethnic country, is in a much better situation. Switzerland is a federal state composed of twenty-six autonomous cantons with a high degree of autonomy. Different ethnic groups have achieved sufficient political participation through this unique federalism and internally highly developed democracy. Although it has also led to the coexistence of "one country, two federal courts," "18“" one country, two federal universities,"19“"one country, three languages," 20 and even "one country, two capitals," 21 in general, all ethnic groups can basically abide by the conviction that "Switzerland is a nation state." So far no regionalist, nationalist, or sectarian issues that affect national unification have occurred. $^{22}$

In terms of political participation by ethnic minorities, both the achievements and problems of countries that adopt centripetalism such as the United Kingdom, Spain, and Canada are significant. From the perspective of achievements, these countries adopt a system of two levels of political participation at the centrallocal levels. In these countries' central government or federal parliament, a certain number of seats are allocated to areas where minority groups are concentrated such as Scotland, Northern Ireland (UK), Catalonia, the Basque Country (Spain), and Quebec (Canada), so that these areas can effectively participate in national affairs. ${ }^{23}$ Meanwhile, these areas, as minority communities, enjoy a high degree of autonomy.

In the context of the problem, the above-mentioned United Kingdom, Spain, and Canada empower their "ethnic areas" to sufficiently participate in political affairs rather than exchange these areas' loyalty to the countries. Instead, due to the

\footnotetext{
${ }^{18}$ Switzerland has two federal courts, one in the French-speaking district of Lausanne and the other in the German-speaking district of Lucerne.

19 Two federal institutions of higher learning were established, one in Lausanne, the French-speaking district, and the other in Zurich, the German-speaking district.

${ }^{20}$ The federal government requires primary and secondary schools to offer courses of German, French and Italian.

${ }^{21}$ Switzerland has in fact formed the two "capitals": German-speaking Bern and French-speaking Geneva, the former being the federal capital and the latter the "international capital."

${ }^{22}$ An important reason why Sweden's extremely diverse political participation does not threaten the unity of its federation is its permanent external neutrality system and practice for external affairs, which exempt Switzerland from the need for internal mobilization and integration in response to external threats. Therefore, the regional, ethnic, or sectarian factors that are part of such system and practice have lost their due momentum. The Swiss case is quite atypical.

${ }^{23}$ The British government has also set up the Secretary of State for Scotland to be responsible for matters related to Scotland. Of course, after the decentralization of power in 1999, the role of the Secretary of State for Scotland has obviously weakened; the Catalan and Basque nationalist parties in Spain could also participate in the governance of national affairs through alliances with the parties with the most votes, such as the Socialist Workers' Party. In Canada, in addition to being guaranteed a certain proportion of seats in the federal parliament, Quebec is also deeply involved in the operation of the federal government. A French Quebec citizen has served as the prime minister of the federal government many times. The 1985 Canadian Supreme Court Act clearly stated that "at least three of the nine judges of the Supreme Court must be judges or lawyers from Quebec."
} 
deep-rooted concept of "one nation, one country" and "democratic determinism," especially with regards to the catalysis of nationalized or regionalized party systems, the United Kingdom, Spain, and Canada have long faced the challenge of regional separatism (Shaoqing 2017). Under the political conditions of government systems with political parties, an important force that maintains the unity of these countries or contains separatist force is the non-nationalist political parties of autonomous regions. Such parties obtain or influence the political direction of autonomous regions through free elections and party competition to ensure that such regions will not be separated. ${ }^{24}$

France, Germany, and the United States, which adopted liberal homogenization, have not set up separate channels for political participation by ethnic minorities. In these countries, minority groups are either not recognized or are regarded as collections of individual citizens. Their political participation is generally achieved through individual citizens. Of course, systems and practices for the division of electoral districts in these countries have actually played a role in digesting the appeal of collective political participation by minority groups.

It should be pointed out that regarding ethnic minorities' political participation, Western countries actually adopt a policy of strict discrimination (as opposed to the Chinese policy that all ethnicities are equal regardless of the size of their populations). The form of civil rights plus regional autonomy is generally taken in the treatment of the so-called "historical national minorities." The political participation by the above minority groups probably belongs to this situation. For native peoples, whose presence precedes that of the majority ethnicity, they generally adopt a high degree of autonomy in reserved areas. ${ }^{25}$ As for new immigrant ethnic groups, equal emphasis has been placed on civicism and multiculturalism, to encourage them to be integrated and assimilated into mainstream society.

In short, when dealing with political participation by minority groups, there are roughly three types of model in Western countries: consociationalism, centripetalism, and liberal homogenization. Consociationalism emphasizes the unique existence of minority groups and strengthens such unique existence through a series of political arrangements including ethnic (regional) autonomy; centripetalism encourages political participation that crosses ethnic boundaries while recognizing the collective identity of minority groups and resolving their political participation by means of autonomy or otherwise; liberal homogenization does not recognize the existence of collective identity of minority groups. A country solves issues concerning the political participation by minority groups by means of civil rights and regional autonomy.

From the perspective of effect, although consociationalism maximizes the protection of the political participation rights of minority groups, the political process of demarcation by ethnic groups can greatly damage the unity

\footnotetext{
${ }^{24}$ The Liberal Party in Quebec, Canada, and the Citizens Party in Catalonia, Spain, are typical cases.

${ }^{25}$ In Canada, native peoples are also respected as "first nations" and enjoy "prior" political and cultural rights.
} 
of a country. ${ }^{26}$ Centripetalism overcomes the disadvantage of strengthening ethnic boundaries brought by consociationalism to a certain extent, and its idea of cross-ethnic political integration has also achieved some positive results. ${ }^{27}$ However, under the condition that the identity of ethnic groups and group autonomy are recognized, and especially that nationalist parties are recognized, in other words, that the nationalization of parties is lawful, the effect of its ethnic political integration is very limited. ${ }^{28}$ In contrast, liberal homogenization has achieved a certain balance in protecting minority groups' rights and safeguarding national unity.

With regard to the ethnic minorities' political participation, China, under the leadership of the Communist Party of China adheres to the Marxist idea that all ethnicities are equal, which not only overcomes the disadvantages of the solidification of ethnic boundaries and even the separatism brought about by the demarcation by ethnic groups under the models of consociationalism and centripetalism, but also avoids the problem of insufficient political participation caused by liberal homogenization that does not recognize the collective identity of minority groups (and autonomy based on such identity). China has not only realized the dual political participation engaged in by minority groups in Western countries at the national level and autonomous regional level, but also has fully and completely implemented the political participation of minority groups through supplementary legislation on the protection of the rights of dispersed minority groups.

It should be particularly pointed out that China neither engages in party competition nor allows party-oriented political participation by ethnic minorities in major political affairs including ethnic issues, as China has always adhered to the core leadership position of the Communist Party of China. In China, political participation by

\footnotetext{
${ }^{26}$ Belgium's linguistic and ethnic politics have divided almost all the important institutions of this country into two parts. In Belgium, there are two official national languages: one is Flemish and the other is French, used by the Walloons. In terms of leaders of the country, apart from a king and a prime minister, the seats of the cabinet should be taken by two ethnic groups equally. Some ministries are simply divided into two parts. Officials in charge of education include the Flemish Minister of National Education and the French Minister of National Education; and the Minister of Flemish Regional Affairs and the Minister of Wallonia Regional Affairs; and Minister of Regional Affairs of Brussels where the two ethnic groups live together. The House of Representatives is also divided into the Flemish Cultural Committee and the French Cultural Committee. Some political parties are also divided. For example, in 1968, the Christian Social Party was split into the Flemish Christian Socialist Party and the Walloon Christian Socialist Party. The case also applied to the Liberal Party and the Socialist Party. Until the twenty-first century, such dichotomy by language family was not alleviated, but became increasingly serious. Around 2009 , because of the disagreement between members of the two language families, Belgium could not produce a new government for a period of nearly nine months, so that many people thought that Belgium might face disintegration at any time. See Wu Sheng: "Belgian Ethnic and Language Problems," World Affairs, 《世界知识》No.11, 1981.

27 For example, non-ethnic parties appearing in autonomous regions play an important role in dissolving separatism and strengthening national identity.

${ }^{28}$ In practice, this model places the hope of maintaining national unity on the victory of non-nationalist parties in elections. The uncertainty of electoral politics determines the uncertainty of national unity. The Scottish and Catalan separatist movements that have appeared and culminated in recent years are the best examples.
} 
minority groups is an integral part of the country's political process, ${ }^{29}$ and no ethnic autonomous areas at any level have their own independent political participation space. The design and practice of China's system not only guarantee the political participation rights of minority groups, but also effectively avoid the dilemmas and odd circles that Western countries cannot escape in dealing with the political participation by ethnic minorities and the guaranteeing of national unity.

\section{Comparison of ethnic economic and social development paths}

\section{The general path of the economic and social development of ethnic minorities}

The economic and social development of ethnic minorities is an important aspect that affects ethnic relations, and also an important content of national economic and social development. Generally speaking, the economic and social development paths open to ethnic minorities can be roughly divided into two categories. One category can be summarized as "free competition"; the other can be attributed to "national coordination." The so-called "free competition" means that the economic and social development of ethnic minorities is mainly determined by the free competition of members of minority groups or autonomous units where the members are located. Under the "free competition" path, the economic and social development of ethnic minorities is mainly determined by the "market." ${ }^{30} \mathrm{Here}$, the main responsibility of the government is to provide systems and rules to ensure or maintain the normal operation of the market.

So-called "national coordination" means that the economic and social development of ethnic minorities is mainly determined by the behavior choices of the (central) government on the basis of following the general economic and social development laws. Under this path, the government intervenes in the economic and social development of the country through a series of policies, legislation, and specific administrative actions, to seek the economic and social development levels of members of ethnic minority groups or autonomous units where the members are located, that are roughly equivalent to those of major ethnic groups and the areas where they are located.

As far as the ideal category is concerned, most Western countries belong to the "free competition" category, while socialist countries, including reformed socialist countries like China, belong to the "national coordination" category. ${ }^{31}$ Of course, such distinction is not absolute. In fact, while adhering to "free competition," in certain historical periods, some Western countries generally adopted certain approaches

\footnotetext{
29 This is self-evident at the national level and at the level of political participation by dispersed minority groups. In dealing with the very difficult issue of "ethnic autonomy" in many Western countries, the Chinese government "adheres to the combination of unification and autonomy, and the combination of ethnic and regional factors." In China, autonomous organs are not independent and autonomous, but should be subject to higher-level party and political leadership and domination.

30 The market here may be either an "economic" or "social" market, or a "political" market.

${ }^{31}$ An important foundation or basis for this distinction is the land rights system. Western countries generally adopt private land ownership, while socialist countries, including China, generally adhere to stateowned and collective land systems.
} 
similar to national coordination for certain ethnic minorities and ethnic groups; similarly, some socialist countries, including China, have generally adopted some "free competition" or "marketization" strategies to strengthen the self-development capabilities of ethnic minorities and ethnic areas while adhering to national coordination.

\section{Comparison of China's and major Western countries' economic and social development paths and effects}

In terms of strengthening the economic and social development of ethnic minorities, the common practice in Western countries is "state neutrality," allowing ethnic minorities and members of ethnic groups to "freely compete" with ethnic majorities and majority groups in the market and social fields. In this regard, France is typical. Regardless of the locale (Brittany, Corsica, etc.), with certain attributes of ethnic groups, or a large number of new immigrants (generally refugees) from the Maghreb region of Africa, Yugoslavia, Southeast Asia, South Asia, and the Middle East, the French government has adopted a "uniform" civic policy. However, due to weak anti-discrimination measures, the difficulties of minority groups to socially integrate, or for other reasons, a large number of new immigrants have been marginalized and impoverished in practice. Specifically, due to ethnic, cultural, and religious differences, among the new immigrant groups, the marginalization and impoverishment of Muslims is the most obvious. Their education level is significantly lower than the French average level, while the unemployment rate is much higher than the French average. Taking the town of Clichy-sous-Bois in the northeastern suburb of Paris as an example, "There is always a strong atmosphere of isolation and abandonment. One-fifth of the 28,300 residents in Clichy are unemployed, and half of the people in some residential areas do not have jobs." Residents of the town of Clichy-sous-Bois believe that their "foreign accents, names, and suburb postal codes will make the bosses retreat." An experiment at the University of Paris, using the identity curve, also shows that interview opportunities using names of French people are five times more than those using North African names. The Institute Montaigne pointed out in a "landmark" report in 2004 that the severity of racial discrimination "could not even be dreamed of." The best way to explain the marginalization and impoverishment of the French Muslim community is to count the number of Muslim prisoners in French prisons. It is estimated that $60 \%$ of the people serving sentences in French prisons are from a "cultural or ethnic origin" Muslim immigrant group. ${ }^{32}$ In 2005, there was a Paris riot that shocked both China and other foreign countries. After the incident, the French government was aware of the serious consequences of poverty and marginalization to a certain extent, and promised to alleviate the huge gap in economic and social development of minority groups by strengthening anti-discrimination and taking certain intervention

\footnotetext{
32 For the above contents, please refer to Zhuang Zi's translation: "French Minority Issues," Global View, 《环球视野》May 4, 2010, No.290; More than Half of French Prisoners Are Muslims: Report, https://www.blaz ingcatfur.ca/2014/10/26/more-than-half-of-french-prisoners-are-muslims-report/. Since French law prohibits statistics based on religion or ethnicity, this figure is controversial.
} 
measures. ${ }^{33}$ However, due to the institutionalized "legal equality" idea and practice, the French government could not fundamentally solve this problem. ${ }^{34}$ Since the 1960s, "special regions" in France, such as Corsica, Brittany, and the Basque Country, have also expressed strong dissatisfaction due to the serious imbalance in economic and social development. Some regions have even showed signs of separatism (Yuyao 2017).

The United States generally belongs to the "fair competition" path. After World War II, the United States continued to adopt an "isolated but equal" policy for its African-American minority group. After two hundred years of slavery, segregation, and discrimination, African-Americans in the United States have been completely marginalized and impoverished in all economic and social aspects. In the 1960s, the civil rights movement, with African-Americans as the main force broke out. In order to protect the interests of the ruling class and save the social order that was on the verge of collapse, the United States' state apparatus - the Congress, the President, and even the judicial system fully intervened in the unfair state of African-Americans' economic and social development. Through congressional legislation, presidential executive orders, and judicial rulings by the US Supreme Court, with "reserved indicators," "preferential," "quotas" and other rare and obvious methods in the history of the United States, they directly intervened in the economic and social development of the country. After more than thirty years of national intervention, the overall situation of minority groups in the United States has begun to change. ${ }^{35}$ Over the last two decades of the twentieth century, especially since the beginning of the twenty-first century, with rising domestic opposition to "reverse discrimination" and the continued solidity of structural discrimination, as well as the combined effect of economic differentiation and identity politics caused by globalization, the improvement in the situation of minority groups and inter-ethnic relations achieved through state intervention

\footnotetext{
${ }^{33}$ Then French President Chirac promised that "the government will take large-scale comprehensive measures to solve issues of discrimination against minorities." Then French Prime Minister De Villepin also announced that "reduced public funding for grassroots community management organizations will be restored to solve the housing, employment and crime problems that have long plagued immigration areas." In practice, in order to help immigrant minority students, the French government provides additional help for schools with a large proportion of immigrant students, to reduce the "learning failure" through the use of the "Priority Education Area" project in the state's "Urban Policy." See Zhou Shaoqing: Dimension of Ideas of Rights - Taking the Protection of Minority Rights as an Example, 《权力的 价值理念之维》 China Social Sciences Press, (中国社会科学出版社) 2016 Edition, p.218.

${ }^{34}$ The French government prohibits the collection of any demographic data based on ethnicity, religion, or culture, and lacks an understanding of the economic and social development of its minority groups. Therefore, it is impossible to undertake effective policies or legislative measures to resolve the serious marginalization and impoverishment of minority groups according to their specific development status. It is worth noting that since the beginning of the twenty-first century, the economic and social conditions of the French minority groups have not improved, and have deteriorated as a whole with the rise of the refugee crisis and far-right influence.

${ }^{35}$ Among people of color, including African-Americans, more than one-third of their populations have begun to enter the middle class. African-American mayors and members of congress are not uncommon. See Zhou Shaoqing, "Primary Discussion about Affirmative Actions"(I, II, III and IV), China Ethnic News, Theoretical Edition, January 18 and 25, 2013, February 1 and 8, 2013.
} 
since the 1960s in the United States has been greatly affected, and ethnic conflicts have been in great danger of returning to the front of history.

From the perspective of autonomous units where ethnic minorities are located, the effect of the "free competition" path is even more intriguing. Under the free competition path, autonomous units where ethnic minorities are located not only face the "market," in their economic and social development, but also engage in various games with the central government. The result is that if the economic and social development of an autonomous unit is significantly better than that of other regions or the national average, such an autonomous unit may file a greater claim for autonomy in order to preserve its own development achievements rather than have such achievements "withheld or supplemented" by the central government. In some cases, autonomous units with greatly enhanced economic and social development capabilities may even demand to separate from their country and live a prosperous life alone. ${ }^{36}$ If the economic and social development of an autonomous unit is significantly lower than that of other regions or the national average, such an autonomous unit may demand to expand the autonomy to realize the "right of equality" between the autonomous unit and other regions. If the economic conditions improve or outperform other regions or the national average, such an autonomous unit may repeat the above-mentioned claim of a developed autonomous unit until it demands separation or independence. ${ }^{37}$

With regard to the economic and social development of ethnic minorities, the Chinese government's approach has attracted worldwide attention. Different from the declaration of "state neutrality" by Western countries, the Constitution of the People's Republic of China and other laws and regulations prescribe the obligation of "state assistance." 38 This obligation of "assistance" is not only reflected at the individual level, but also at the level of an autonomous unit. In China, the economic and social development of minority groups not only involves the vital interests of minority groups, but also forms an integral part of the economic and social development of the entire country. "This is the society to be enjoyed by each and every one

\footnotetext{
36 This is the case in Catalonia in Spain and Scotland in the United Kingdom.

37 This is evident in Belgium. When the Flemish region lagged far behind other regions, especially the Wallonia region, the Flemish people appealed to the central government for "equal rights"; when the Flemish region later caught up with economic and social development, greatly surpassing that of the Wallonia region, the Flemish challenged the traditional power pattern and demanded the redistribution of state power according to the new level of economic and social development, until the once-unitary Belgium was transformed into a federal system; they even eventually proposed the establishment of their own country, fundamentally threatening Belgium's national security and territorial and sovereign integrity.

${ }^{38}$ The preamble of the Chinese constitution states that "the state shall do everything possible to promote the common prosperity of all the peoples of China." Article 4 states that the state "provides assistance to regions inhabited by ethnic minorities in order to accelerate their economic and cultural development"; Article 122 provides that "the state provides financial, material, and technical assistance to ethnic minorities, helping to accelerate their economic and cultural development"; Articles 8, 55, 64, 69, and 71 of the Law on Regional Ethnic Autonomy stipulate in detail the state's assistance obligation. The white paper on human rights, called "Progress in China's Human Rights in 2013," proposed to "continue to implement preferential policies for ethnic minorities."
} 
of us" is China's most typical idea for solving the economic and social development issues of minority groups.

In order to allow ethnic areas with weak starting points and weak development foundations to catch up with the economic and social development levels of other areas as soon as possible, the Chinese government has adopted all possible policies and legal means. ${ }^{39}$ After decades of development, the economic and social development of Chinese ethnic minorities has been greatly improved: some ethnic minorities have entered the socialist period directly from the primitive society and serfdom periods; the development indexes, in education and other fields, of another dozen ethnic minorities have exceeded the national average; more ethnic minorities have benefited from the various "priority arrangements" and "special arrangements" measures of the country, and thus the level of economic and social development continues to increase.

The economic and social development of Chinese ethnic minorities has benefited from the Chinese government's strong ability to coordinate the country. Under the national coordination path, the economic and social development of ethnic minorities has been included in the overall national development strategy. The state has the power (and the right) and ability to implement a balanced development strategy in various regions, including ethnic autonomous areas. The state's overall planning measures are not only conducive to the realizing of social justice in underdeveloped ethnic minorities' and ethnic autonomous areas, but also, more importantly, conducive to maintaining the balance and stability between regions, thereby preventing the occurrence of the phenomenon that endangers national security and social stability due to "division caused by wealth" or "chaos caused by poverty."

With regard to the economic and social development of ethnic minorities and ethnic groups, the largest problem in Western countries' free competition path based on state neutrality is that the central government lacks legitimacy and legal basis for intervening in the economic and social development of ethnic minorities and ethnic groups, as well as necessary resources and effective means for such intervention. Under the free competition path, the economic and social development of ethnic minorities and ethnic groups is extremely unstable and unbalanced. From the perspective of individual members, a large number of members of ethnic minority groups are lost in competition, and marginalized and impoverished by the market and society due to the country disregarding their vulnerable situation and indulging the "natural" elimination function of economic and social markets. When such marginalization and impoverishment are highly coincident with regional boundaries of ethnic groups, and there are uncontrollable political and social crises, the government will begin to adopt national interventions to temporarily ease the crisis.

From the perspective of an autonomous unit, the economic and social development of the autonomous unit is in a spontaneous or laissez-faire state, to a large

\footnotetext{
${ }^{39}$ In addition to clarifying the state's obligation to help the economic and social development of minority groups in important legal documents such as the constitution, the Chinese government has adopted dozens of means - finance, taxation, various development plans, schemes and projects, counterpart support, and targeted poverty alleviation, and targeted policy arrangements in education and employment, to help the development of minority groups and minority-populated regions with full efforts. This practice is rare in the world.
} 
extent due to the orientation of free competition. In practice, those autonomous units that are in a leading position in economic and social development are often dissatisfied with the central government's redistribution policy, and after bargaining with the central government without results, they attempt to "set up separate governments," moving towards separatism. Autonomous units that lag behind in economic and social development attempt to change the unfavorable economic and social development situation or make up for the shortcomings in economic and social development by expanding autonomy. Some autonomous units even propose independent or separatist claims accordingly.

In China, however, the state first strongly confirms the national obligation to help with the economic and social development of ethnic minorities from the Constitution, and on this basis, through a series of policies, laws, and administrative means, directly or indirectly intervenes in the national economic and social development to help with the economic and social development of ethnic minorities. The development idea and practice of the Chinese government that "no one is dispensable" not only prevents individual members of ethnic minorities from the fate of being marginalized and impoverished, as in Western countries, but also avoids imbalances in the development of various ethnicities and the social injustice caused by the economic and social development model featuring separate administration, as well as the various separatist problems arising therefrom.

\section{Comparison of paradigms of national languages and cultural rights protection}

\section{Main paradigms of minority language and cultural rights protection}

The right to language and culture is among the most relevant in the system of minority groups' rights. It is related to the maintenance of minority groups' traditions and characteristics, as well as to their political participation, economic and social development, and all aspects of life. At the same time, the language and cultural rights of ethnic minorities are also important aspects of the relations between minority groups and the countries to which they belong. Whether the state guarantees the language and cultural rights of minority groups, as well as the methods and degree of guarantee, are closely related to the state's historical experience, cultural traditions, ethnic group structure and relations, state system, and state structure. Generally speaking, there are two basic paradigms in the guarantee of minority groups' language and cultural rights. One is to protect the civil rights of individual members of minority groups, and the other is to protect the civil rights of individual members of minority groups while protecting their group rights. The former paradigm is mainly applicable to countries that have a high degree of homogeneity of the national ethnic structure or that are established as countries based on civicism, while the latter is mainly applicable to countries with strong heterogeneity of the civic ethnic structure. 


\section{Comparison of China's and major Western countries' paradigms of minority language and cultural rights protection}

Western countries were the first to face the issue of the protection of minority groups' language and cultural rights. In the course of building nation-states over centuries, how to treat the language and cultural rights of minority groups has always been an important political issue faced by the nation-states of Western Europe. Historically, Western countries have two characteristics in the protection of the language and cultural rights of minority groups. ${ }^{40}$ One is the regulation or legislation of rights protection, often issued before international bilateral or multilateral treaties $^{41}$; the other is that the choice of legislation on rights protection is obviously passive, that is, the main reason for choosing to protect the language and cultural rights of minority groups is external pressure, or the internal need for maintaining national security.

After World War II, as influenced by the international liberalism of "equality of all citizens," many Western countries adopted the policy of "citizenization" for their domestic minority groups. In the United States and Canada, the languages and cultures of native minorities had been assimilated or eliminated because they were regarded as an obstacle to the groups' "modernization and citizenization." In the countries of Western Europe, the "citizenization" movement was in full swing, and the languages and cultures of indigenous minority groups in some countries had been systematically suppressed. ${ }^{42}$

After the US civil rights movement in the 1960s, and especially after the rise of multiculturalism in Canada in the 1970s, Western countries began to adjust their existing citizen homogenization policies on the language and cultural rights of minority groups. By the 1980s, under the two-way interaction of Western political philosophy and international human rights law (Kymlicka 2019), the language and cultural rights of minority groups attracted extensive attention in Western mainstream society. Since then, the United States, Canada, and other countries have begun to fully protect their linguistic and cultural rights through native autonomy. For immigrant minority groups, the policies of the United States and Canada are different: although the former also provides financial assistance for various immigration organizations, the purpose is mainly to support integration, rather than to preserve immigrants' cultural traditions, ${ }^{43}$ while the latter aims to allow various ethnic groups to preserve and develop their own culture and value within Canada (Lipset 1990).

During this period, even France, which was a model of civicism, began to clearly recognize the cultural differences of immigrant minority groups; the languages of some indigenous minority groups, such as the Bretons, were given official language

\footnotetext{
40 The "minority group" here mainly refers to the so-called "historical ethinc minority."

41 This was very obvious in the early days of European nation-states. In fact, after the Cold War, Europe still continued with this feature.

${ }^{42}$ For example, minority groups such as Catalonia and the Basque in Spain under the rule of Franco.

43 Retrieved from [Canada] Will Kymlicka, translated by Zhou Shaoqing et al:: Multiculturalism Policy Indicator System Database - United States (Unpublished).
} 
status by regional committees. When the French constitution was revised in 2008, France also added "regional language is the heritage of France" in Paragraph 1 of Article 75 thereof. After the Cold War, Western countries largely continued their historical practices in protecting minority groups' language and cultural rights. ${ }^{44}$

In general, after World War II, Western countries generally adopted a policy on differentiated treatment of minority groups' language and cultural rights. For native minorities, the paradigm of protection of collective rights was basically adopted; for indigenous minority groups, the paradigm of protection of collective rights plus individual rights was adopted; for new immigrant minority groups, the paradigm of individual rights was mainly adopted. This different choice of political strategy was related to the different historical experiences and actual conditions of various minority groups, and further closely related to the consideration of political interests by the ruling class. ${ }^{45}$ Since the twenty-first century, with the impact of the refugee crisis, some Western countries have imposed restrictions on the languages, and especially on the cultural rights, of immigrants. ${ }^{46}$

In stark contrast to Western countries, the Chinese government's protection of ethnic minorities' language and cultural rights is not based on treaty supervision between countries or other external pressures, nor is it based on utilitarian considerations to maintain national security. The Chinese government's process of protecting the language and cultural rights of minority groups was almost synchronized with the establishment of the PRC. Since the 1950s, the Chinese government has conducted a comprehensive investigation into and research on the languages of ethnic minorities, and established specialized ethnic-language working institutions and research institutions to train professionals in ethnic languages. In strong contrast

\footnotetext{
44 This was particularly evident in Europe after the Cold War. In order to maintain the security of the region and related countries, the European Council and other countries promulgated a series of treaties (or conventions), with suggestions or decisions such as the European Charter for Regional or Minority Languages (1992) and the Framework Convention for the Protection of Ethnic Minorities (1995). In these documents, the cultural and language rights of minority groups are clearly guaranteed. For example, the "Language Charter" confirms that the use of minority languages in private and public life "is an inalienable right." See "Preamble of European Charter for Regional or Minority Languages," European Treaty Series, No.148.

45 For native minorities that have historically suffered cultural loss and do not threaten national identity in reality, territorial autonomy should be generously allowed; for indigenous minority groups with the concept that one nation is one state, certain forms of regional autonomy plus individual citizenship rights should be granted under the premise of avoiding their separation; for immigrant minority groups who come voluntarily to large extent, only their "multi-ethnic rights" are protected. The minority languages and cultural rights under these three paradigms show great differences.

46 This is very obvious in the old continent countries such as France, while at the same time, in the new continent countries (such as Australia, Canada, New Zealand, the United States) and the minority areas of the old continent countries (such as Scotland and Northern Ireland in the United Kingdom), the cultural rights of immigrant minority groups are better protected. It is worth noting that the Republic of Ireland has recently joined the ranks of the new continent countries. In the code of police dress, immigrants with different religious backgrounds are openly allowed to wear their national or religious clothing. In the notice for recruiting police officers, the head of the Irish Police said that "the police force of the Republic of Ireland needs to become more diverse to more appropriately reflect the society we serve." "We want to encourage people from all walks of life to join us." "We seek diversity in terms of the background of police officers and the skills of the police force." See BBC NEWS, "Garda Síochána Allowed to Wear Turbans and Hijabs", 4 April 2019.
} 
with the attempts of some Western countries to eliminate ethnic minorities' languages, the Chinese government has helped the Zhuang, Buyi, Miao, Naxi, Lisu, Hani, Wa, Dong, Jingpo, Tu and other dozens of ethnic minorities create or improve their written languages (Shaoqing 2016).

In terms of language rights protection, China has almost forty laws and regulations to ensure the rights prescribed by the constitution that ethnic minorities have to employ and develop their own spoken and written languages. Whether in national politics and social life, or in the fields of administration, justice, education, news, publishing, broadcasting, or film and television, minority groups' language rights are clearly and effectively guaranteed. With regard to cultural rights, the traditions and customs of various minority groups are respected and protected by the state (SCIO 2013).

It is worth noting an outstanding phenomenon related to the Chinese government's protection of ethnic minorities' cultures, and a proportion of intangible cultural heritage of ethnic minorities in the entire country. Among the list of 1372 items of national-level intangible cultural heritage compiled by the Chinese government, 492 items belong to ethnic minorities, accounting for 36\%; among the 3068 representative inheritors of national-level intangible cultural heritage items, 862 are minority inheritors, accounting for about $28 \%$. In addition, twenty-one national-level cultural and ecological protection experimental zones have been established nationwide, with eleven located in ethnic areas (Shaoqing 2018a, 2018b).

In China, the language and cultural rights of ethnic minorities are protected by the constitution. ${ }^{47}$ In addition, the state also includes "guaranteeing the cultural rights of ethnic minorities" and "lawfully guaranteeing the rights of ethnic minorities to learn to employ and develop their own spoken and written languages" in the human rights promotion target through the "human action plan." All this forms a strong contrast to Western countries.

With regard to the protection of language and cultural rights, the main difference between Western countries and China is that the former mainly adopts a passive response strategy, and as driven by external pressure or national security motives, often adopts several protective measures; while the latter takes the initiative to adopt systematic protective measures under no external pressure. Regarding the equality of protection, the former divides the protected minority groups into different classes, and adopts different protection standards for different types of minority groups; while the latter takes "equality" protective measures for fifty-five ethnic minorities according to the idea that "all ethnicities are treated equally irrespective of their [population] sizes." In terms of the stability and effect of protection, many Western countries have declared that the "multiculturalism" policy protecting the language and cultural rights of immigrant minorities is a "failure," that their measures protecting the languages and cultures of native minorities have poor effect, and that the languages and cultures of native minorities are generally endangered; China not

\footnotetext{
47 Paragraph 4 of Article 4 of the Constitution of the People's Republic of China (1982) provides that "All nationalities have the freedom to use and develop their own spoken and written languages and to preserve or reform their own folkways and customs;" Article 47 provides that they "have the freedom to engage in scientific research, literary and artistic creation and other cultural pursuits."
} 
only consistently recognizes and respects the language and cultural rights of ethnic minorities, but also actively adopts various political, legal and policy means to protect these language and cultural rights. Over seventy years since the founding of the PRC, the language rights of all ethnicities have been fully exercised, and their cultural rights have been respected and guaranteed. The cultural prosperity of all ethnicities in China has reached a new level.

\section{Comparison of national cohesion and social (or ethnic) unity construction models}

\section{General models of national cohesion and social (or ethnic) unity construction}

National cohesion and social (or ethnic) unity are major issues that modern nationstates generally face. The so-called national cohesion refers to the "inward cohesion and outward attraction of a country to meet the material, spiritual, political, cultural, security and other needs of different ethnicities, political parties and people on the basis of common ideals, goals and interests" (Xueqian 2004; Duogui et al. 2016). Social (or ethnic) unity refers to the fact of interdependence and joint relationship between people or between ethnic groups in a particular society, and the recognition of the state of such fact.

Generally speaking, there are roughly three models or paths of national cohesion and social (or ethnic) unity construction. The first is "civic nationalism," which emphasizes the political attributes of the "nation," and treats the nation as a union or community of individuals who enjoy equal civil rights and freedom. National cohesion construction and social unity under the model of civic nationalism are based on the common political beliefs and values of all citizens, even if these citizens have obvious differences in skin color, race, and religion. The simple tenet of civic nationalism is that bringing people together or maintaining social unity is a common law, not a common origin.

The second is ethnic nationalism, which emphasizes "non-selective" factors such as ethnicity, culture, and pedigree, and plays a role in national cohesion or social unity construction, and believes that the power to unite people's hearts and promote unity is not an abstract value principle, but "bloodline," "race" or "background." Ethnic nationalism has a strong "return to ancestry" characteristic.

The third is deemed to be between civic nationalism and ethnic nationalism to some extent. This model not only recognizes the role of common political beliefs in national cohesion and social unity construction, but also values the role of a common "origin" and other "non-selective" factors. In practice, the vast majority of nation-states adopt this model. The difference lies only in the degree of civic nationalism and ethnic nationalism. Therefore, in essence, there are two models or paths of national cohesion and social (ethnic) unity construction. One can be called a "procivic-nationalism" model and the other a "pro-ethnic-nationalism" model. ${ }^{48}$

\footnotetext{
48 It is worth noting that although the two models distinguish between "citizens" and "ethnicities," they are actually based on citizen politics.
} 


\section{Comparison of China's and major Western countries' national cohesion and social (or ethnic) unity construction models}

The West is the birthplace of nation-states featuring the characteristic of "one nation one state," but most Western countries are de facto multi-ethnic states. In order to forge national cohesion and social (or ethnic) unity under the national conditions of ethnic, regional, or cultural diversity, whether it is a country that adopts a "pro-civic nationalism" model or a "pro-ethnic nationalism" model, the sign of civic politics is upheld in practice. In France, the foundation of national cohesion and civic unity construction is the so-called "undifferentiated French citizen." In order to prevent the possible impact and centrifugal tendency of "ethnic groups" or other "special groups" on French cohesion and social unity, France has adopted the practice of not recognizing any sub-state group.

In the United States, apart from Native Americans, the civicization policy is applied to minorities, whether they are African-American or new immigrant groups, and the "American nation" has become an important tool for forging American national cohesion and social unity. In Britain and Spain which adopted a pro-ethnic-nationalism model, apart from relying on civicism, national cohesion and social unity construction also adopts regional-based ethnicism (the states recognize a certain ethnic group's collective rights in the form of regional autonomy). The states recognize the collective political identity of minority groups in exchange for their loyalty or non-centrifugation to the states. In order to agglomerate and unite diverse ethnic groups, Canada has adopted a political strategy of cultivating multicultural citizens. In Switzerland and Belgium, in order to maintain the integrity of the federation and social (or ethnic) unity, the federal government adopts a dual strategy of civicism and ethnicism (or regionalism).

In terms of effect, although France has maintained a "single indivisible""French nationality" in form, the social disturbances and the centrifugal tendency of the Corsican and Breton people give French cohesion and social unity a serious threat. It is even more difficult for the citizenization political strategy of the United States to restrain its deep-rooted ethnic contradictions and conflicts. The emerging regionalism (or separatism) in the United Kingdom and Spain (Shaoqing 2018a, 2018b), is the best indicator of the low efficiency and even the failure of their integration policies. In Canada, the multiculturalist citizenship strategy has indeed, on the one hand, brought a significantly positive effect on the country's national cohesion and social unity, so that the "Canadian exceptionalism" with multiculturalism effect has appeared (Shaoqing 2013); while on the other hand, this multiculturalist inclusive strategy has not completely eliminated the threat posed by the Quebec separatist movement to the unification and security of the federation. Switzerland and Belgium are two opposite examples. The former generally maintains the unity and social unity of the federation, while the latter has a serious separatist crisis.

In recent years, with the continuous emergence of various contradictions in the process of globalization, the pro-civic nationalism model adopted by Western countries has an incipient tendency for a transition to the pro-ethnic-nationalism model. European ethnic nationalism, characterized by white supremacy or Christian conservatism, began to challenge the pro-civic nationalism model created since World 
War II, and increasingly fierce right-wing political and social movements with antiimmigration and anti-Islam acting as kinetic energy, not only seriously threaten the ethnic integration achievements achieved by Western countries since World War II, but also threaten the security of the supranational organization, the EU, itself.

Due to major differences in the country's historical experiences and actual political systems, the Chinese government has chosen a path that is significantly different from that of Western countries in terms of national cohesion and social (or ethnic) unity construction. The Chinese path cannot be simply attributed to a pro-civic nationalism model or a pro-ethnic-nationalism model, and cannot be regarded as a mixture of the two. The Constitution of the People's Republic of China guarantees the equal rights of all ethnicities, as well as all citizens; it not only prescribes the political participation right of all ethnicities, but also prescribes their equality rights in economy, society, and culture; it not only distinguishes between all ethnicities, but also prescribes that they are indiscriminate national masters. Western countries often have binary opposition between "citizens" and "ethnicities," and between citizenship rights and ethnic identity related to national cohesion and social unity construction. Unlike Western countries, the Chinese government has subtly reconciled citizenship and ethnic culture identity through the core values of socialism, and closely combined the national identity of citizens with their traditional cultural identity. ${ }^{49}$ This advantage of China comes from its inclusive traditional culture, and is closely related to its critical appraisal of the concepts of Western nation-states and citizens.

In short, on the issue of national cohesion and social unity construction, the most important feature of the Chinese model is that it overcomes the binary opposition between political identity and cultural identity that has long plagued Western countries, and highly integrates political values with the values of traditional culture. This integration is further consolidated in its political and administrative institutional establishment, thereby forming a strong cohesion and social unity that can mobilize its fifty-six ethnicities. Although due to various reasons (such as the influence and penetration of geopolitics and international separatism), "three forces" have also appeared in individual regions, on the whole, the unity of all ethnicities in China and the cohesion of the Chinese nation are on the rise, and China's national cohesion and social unity are at the best period in history.

National cohesion and social unity construction is a major issue facing all countries in the world today. Before World War II, Western countries were generally in a period of forging national cohesion and social unity with "assimilation" or "homogenization." After World War II, due to repeated setbacks for worldwide progress and assimilation policies, Western countries began to turn to new paths or models oriented towards citizen (individualist) egalitarianism with limited recognition of ethnic identity. In such a process, tensions and confrontations between civic nationalism and ethnic nationalism emerged. Because it was difficult to fundamentally solve the relations between the construction of citizenship and the different cultures of various ethnic groups, many countries fell into difficulties in the

\footnotetext{
49 "Traditional culture" here is obviously the synthesis, summation, and refinement of the cultures of various ethnicities including the Han nationality.
} 
process of national cohesion and social unity construction. ${ }^{50}$ Since the twenty-first century, ethnic nationalism in Western countries has risen, while national cohesion and social unity have been severely damaged. Separatism has emerged in some countries, while different degrees of ethnic conflicts and ethnic riots have occurred in other countries.

In contrast, due to the relatively successful resolution of the relations between citizenship and ethnic identity, and between political identity and cultural identity, China's national cohesion and social unity have been steadily strengthened since the founding of the PRC in 1949. Unity of all ethnicities and China's national cohesion is at their all time best. This gap between China and Western countries is related to their respective political choices on the one hand, and is inseparable from their historical traditions on the other: since ancient times, China has advocated the "unification" tradition as seen in the sayings "great unification" and "unity in diversity." On the contrary, Western countries, deep in their values, still pursue the tradition of "differentiation" by nation-state, that is, "one nation one state" formed in modern times.

\section{Conclusion}

In the middle of the twentieth century, China and Western countries entered the post-war reconstruction period at about the same time. Seventy years later, China and the Western world have significant differences in their respective "ethnic issues." In the final analysis, such differences reflect the differences in the ideas, systems, and cultures of the "two worlds" in dealing with different groups. Conceptually, China, under the leadership of the Communist Party of China, guided by the Marxist idea of the equality of all ethnicities, has formed a community of destiny that transcends the distinction of rights. In contrast, the main motivation for Western countries to protect minority groups is to maintain their respective national security and social stability. ${ }^{51}$ In fact, until the middle of the twentieth century or even later, Western countries still adopted assimilationism to deal with ethnic issues. Institutionally, China adheres to the socialist system and endeavors to achieve substantive equality among all ethnicities through the power of the whole country and a series of political, economic, social, cultural, and ecological policies

\footnotetext{
${ }^{50}$ In the face of ethnic differences, Western countries have always had two opposite choices. One is based on individual citizen rights and denies differences, which leads to the disapproval and centrifugation of minority groups; the other is based on collective rights and magnifies differences-federalism until the country cannot be reunited, for example, Belgium. See Martin O. Heisler, "Managing Ethnic Conflict in Belgium, Ethnic Conflict in the World Today," The Annals of the American Academy of Political and Social Science, Vol.433, 1977.

51 A strong piece of evidence is that their standards for protecting ethnic minority groups were first formed in international or regional laws, not their domestic laws. In fact, these protection standards are the product of their mutual struggles, restraints and supervision, with great passiveness and external drive. After the Cold War, the increase in the number of regional human rights conventions, treaties and agreements for the protection of ethnic minority groups in Europe further illustrates this point.
} 
and legal measures; while capitalist-system-based Western countries mainly rely on the spontaneous forces of the market and society to maintain the legal formal equality of various ethnic groups, inevitably leading to serious de facto inequality among those groups. The differences between the "two worlds" are manifested in the cultural perspectives. Western cultures advocate competition, and are accustomed to treating different cultural groups as objects to conquer, achieving integration only through assimilation or the elimination of different groups. This cultural idea is not only reflected in domestic ethnic relations, but also between countries. Chinese culture advocates "harmony in differences," and China is good at relying on mutual cultural integration to achieve integration. Similarly, this cultural idea is not only reflected in domestic ethnic relations, but also between countries. Different ideals, systems, and cultural concepts lead to the different ethnic relationships and current situations of development between the "two worlds." In China under the leadership of the Communist Party of China, relations between ethnic groups are harmonious and positive, and the development of all ethnicities tends to achieve real equality. In Western countries in the same period, ethnic (or racial) relations remain relatively stable with fluctuations from time to time, and the development gap between ethnic groups has a trend of further expansion. In short, under the leadership of the Communist Party of China, the Chinese path of integration and development among all ethnic groups has achieved significant historical achievements.

Acknowledgements Thanks to Wang Yanzhong, Yang Shengmin, Chen Jianyue and other experts and scholars.

Author's contributions Shaoqing Zhou conducts the research and writing, and read and approved the final manuscript.

Funding This paper is the phased research result of the "70 Years of Chinese Ethnic Integration and Development" project chaired by researchers Gao Xiang and Wang Yanzhong of the Chinese Academy of Social Sciences.

Availability of data and materials Not applicable.

\section{Declarations}

Ethics approval and consent to participate Not applicable.

Consent for publication Not applicable.

Competing interests Not applicable.

Open Access This article is licensed under a Creative Commons Attribution 4.0 International License, which permits use, sharing, adaptation, distribution and reproduction in any medium or format, as long as you give appropriate credit to the original author(s) and the source, provide a link to the Creative Commons licence, and indicate if changes were made. The images or other third party material in this article are included in the article's Creative Commons licence, unless indicated otherwise in a credit line to the material. If material is not included in the article's Creative Commons licence and your intended use is not permitted by statutory regulation or exceeds the permitted use, you will need to obtain permission directly from the copyright holder. To view a copy of this licence, visit http://creativecommons.org/licen ses/by/4.0/. 


\section{References}

Duogui, Yang, et al. 2016. Evaluation Research on National Cohesion of Major Countries in the World. Bulletin of Chinese Academy of Sciences, 《中国科学院院刊》: 11.

Franklin, J. H., Zhang Bingzi et al. (trans.): A History of Negro Americans, The Commercial Press, (商 务印书馆) 1988. 543.

Hongyuan, Zuo. 2012. Conflicts and institutional design: A theoretical comparison of Consociationalism and centripetalism. Ethno-National Studies 5.

International Human Rights Law Curriculum Project Team (IHRLCPT). 2002. International Human Rights Law Curriculum (Document Collection), Vol. 2, China University of Political Science and Law Press, (中国政法大学出版社). 1, 5, 27.[Canada].

Kymlicka, Will. 2019. translated by Zhou Shaoqing, He Hongmei: "Minority Rights in Political Philosophy and International Law". Foreign Theoretical Trends 3.

Lenin, Vladimir. 1914. "Corrupting the Workers with Refined Nationalism”, Collected Works of Lenin, 《列宁选集》Vol. 25, People’s Publishing House, 1988. 153.

Lipset, Seymour Martin. 1990. Continental Divide: the Values and Institutions of the United States and Canada. New York: Routledge.

Marx, Karl and Friedrich Engels. (1847). “On Poland”, Marx/Engels Collected Works, 《马/因选集》 Vol. 1 People's Publishing House, 1972. 290.

Mill, John Stuart. 1982. translated by Wang Xuan: Representative Government, 《代议制政府》. The Commercial Press. 223-225.

Shaoqing, Zhou. 2013. Political and social effects of multiculturalism policy: A study of the object of Canada. Academics 12.

Shaoqing, Zhou. 2015a. Analysis and comparison of several ethnic ideas. Academics, 《学术界》: 1.

Shaoqing, Zhou. 2015b. On Marxist value idea on equality of all ethnicities. Journal of World People Studies: 5.

Shaoqing, Zhou. 2016. Dimension of Ideas of Rights - Taking the Protection of Minority Rights as an Example, 275.

Shaoqing, Zhou. 2017. Analysis of Canada's Strategy Safeguarding National Sovereignty. Academics 10.

Shaoqing, Zhou. 2018a. Criticism and Reflection of the National Separatist Movement in Western Europe - Taking Independence Movements of Catalonia and Scotland as Examples. Journal of World People Studies 1.

Shaoqing, Zhou. 2018b. Chinese Human Rights Cause in Ethnic Minorities Having Made Historical Progress. China Ethnic News 19.

Shiyin, Chang. 2009. For Harmony through Difference: Study on the Political Thoughts of Contemporary Multiculturalism in the West, 《异中求和》, 344. People's Publishing House.

State Council Information Office (SCIO). (2013). White Paper: Progress in China's Human Rights in 2013 (released in May 2014).

UN General Assembly Resolution 217C (III), 1948.

Xueqian, Liu. 2004. Enhancing the Cohesion of Contemporary China, 29. People's Daily.

Yuyao, Chen. 2017. Generation, Development and Status Quo of the Bretonian Cultural Identity Characteristics. Journal of World People Studies 3.

\section{Comments}

Publisher's Note Springer Nature remains neutral with regard to jurisdictional claims in published maps and institutional affiliations. 